\title{
The Effectiveness of Information Service Using Contextual Teaching and Learning In Preventing Sexual Abuse
}

\author{
Annajmi Alfath ${ }^{1}$, Firman $^{2}$, Syahniar ${ }^{3}$ \\ ${ }^{123}$ Universitas Negeri Padang, Padang and Indonesia \\ *Corresponding author, e-mail: anna.tanjung26@gmail.com
}

\begin{abstract}
Adolescent sexual behavior that does not comply with the values and norms will lead to sexual abuse. Causes of sexual abuse is the lack of knowledge and adolescent sex education obtained. Knowledge and adolescent sex education can be obtained through counselor. Counselor an important role to provide education and knowledge of sex, because half the time teenagers at school. In providing new knowledge counselor can use contextual teaching and learning, it is intended that the material provided can be understood by students. The study discussed of the efektiveness of information service contextual teaching and learning to prevent sexual abuse of a senior high school students by using the sexual abuse scale. Data analysis technique used were Kolmogorov Smirnov 2 Independent Sample and Wilcoxon Signed Rank Test.The result indicated that overall the sexual abuse students can be prevented by the information service used contextual teaching and learning. The implication of the study might be useful as an innovation for counselor serivice on senior high school.
\end{abstract}

Keywords: Sexual Abuse. Counselor, Learning and Contextual Teaching and Learning

How to Cite: Alfath, A., Firman, F., \& Syahniar, S. (2018). The Effectiveness of Information Service Using Contextual Teaching and Learning In Preventing Sexual Abuse. International Journal of Research in Counseling and Education, 2 (2) 58 - 63, http://doi.org/10.24036/0023za0002

This is an open access article distributed under the Creative Commons 4.0 Attribution License, which permits unrestricted use, distribution, and reproduction in any medium, provided the original work is properly cited. @2018 by author and Universitas Negeri Padang.

\section{Introduction}

Adolescence is one period that should be experienced by individuals in their life. Senior High School (SMA) student are individuals at an early stage of adolescent development. Havighurst (in Kusmiran, 2012) explained that at this time, adolescents have some developmental tasks that they have to achieve in order to develop optimally. One of the developmental tasks to be achieved is to master the ability to foster new and more mature relationships with peers of the same or different gender. Blair and Jones; Ramsey; Mead; Dusek; and Besonky (in Mudjiran, 2007) described the characteristics of adolescent development, one of which is the adolescent has a strong relationship with the opposite sex.

Strong attachment between adolescence is usually based on the existence of sexual drives. (MacMartin \& Wood, 2005; Kusmiran, 2012; Khairunnisa, 2013; Gannon \& Alleyne, 2013; Waldron, Scarpa, Kim-Spoon \& Coe, 2014) explained that the emerging sex drive will shape sexual behaviors. Sexual behavior appears to be controlled by the values that adolescence have (Homma, Wang, Saewyc, \& Kishor, 2012). Values are obtained through the environment, schools, friends, family and society. One of the reason of adolescence sexual abuse is because of the lack of information that they know related to sexual behavior (Fuadi, 2011; Schober, Fawcett, Thigpen, Curtis \& Wright, 2011; Asra, 2013)

Sexual Abuse is all forms of visual behavior (lustful, threatening, sexually suggestive gestures), verbal forms (whistles, gossip, sex jokes, threatening statements), and physical form (touching, pinching, tapping, nudging intentionally, squeezing, approaching unintentionally) that connotes or directs to sexual matters unilaterally and unexpectedly by the targeted person, resulting in negative reactions such as shame, anger, resentment, offended and etc (UNESCO, 2012).

Data from the Indonesian Child Protection Commission (KPAI) in 2016 revealed that complaints of related to adolescence sexual abuse increased since 2014 to 2016. 
Table 1. KPAI Data About Sexual Abuse Cases

\begin{tabular}{|l|c|c|c|}
\hline \multirow{2}{*}{ Problem } & \multicolumn{2}{|c|}{ Years } & 2015 \\
\cline { 2 - 4 } & 2014 & 2016 \\
\hline Children becomed victimsof sexual abuse & 30 & 37 & 51 \\
\hline Adolesences into the abuser of sexual abuse & 14 & 17 & 22 \\
\hline
\end{tabular}

Sumber:KPAI.go.id

Based on the table above, there were 30 cases of child as the victims of sexual abuse in 2014. Among the 30 cases, there are 14 adolescence abuser. By 2015 there were 37 cases of sexual abuse, among which 17 of them were adolescence. In 2016 there were 51 cases of sexual abuse, 22 case conducted by adolescence. KPAI explained that the case against these children were not really reported because the victims and their family did not want to report the incident to law enforcers or KPAI, because they feel embarrassed, but some of them were nor reported because the victims felt unsure that their report will be processed by the law. People who are around the sexual abuse happened sometimes close their eyes and do not want to interfere with the problems (Pasha, 2009; Paramastri \& Priyanto, 2010; Pranungsari \& Kushartati, 2014). Previous studies were (Wohab \& Akhter, 2010; Cromer \& Goldsmith, 2010; Loeb, Rivkin, Williams, Wyatt, Carmona, \& Chin, 2014; Hermayeni, \& Aviani, 2017) that victims of sexual abuse were unwilling to disclose their experiences including to their nuclear family. Based on the study above can be concluded that the sexual abuse is arround the world.

Ananda (2016) explained that sexual abuse can occur due to several factors, such as psychological factors, biological factors, lack of parental attention, lack of knowledge and sex education, using impolite dress, lack of faith, association, and ever been sexually abused. So counselor at school have an important role to prevent the sexual abuse happened (Goldman \& Padayachi, 2005).

Sari (2016) explained that counselors have a responsibility to prevent adolescence from sexual abuse. Adolescents may become victims or become sex offenders (Edinburg, Saewyc \& Levitt, 2006; Plummer \& Cossin, 2016). One way to prevent sexual abuse since is to give students an understanding and knowledge of the positive attitudes of sexuality through information services.

Information services can be provided by counselor to students in groups or in class. The provision of information services can also use learning models, it is intended that the service process provided to achieve the purpose of the service processes and the service processes do not run monotonously. One of the learning models that can be used in the process of information service is Contextual Teaching Learning. Rusman (2010) explained that the contextual teaching and learning model is a learning model that facilitates learning activities to seek, process, and find concrete learning experiences through involvement of student activities in trying, doing and experiencing themselves. Thus, the use of a learning model in the service delivery process can make it easier for students to understand the material in the service process and to relate it to real life.

Based on the results of interviews conducted by the counselor in senior high school in Padang, known in providing information services to students, tend to use lecture and question and answer methods. In addition, by the counselor information service materials related to the prevention of sexual abuse have not been provided to the students. It is characterised by many phenomena that often occur in adolescent life related to sexual abuse. Like sexually labeling a friend, holding a friend's body part by pinching, squeezing and scratching, and joking sexual orientation that makes a friend as a victim feeling embarrassed, angry and hateful.

Associated with the phenomena that often occurs in adolescents at school, the need for a service to prevent it, one of the information services using Contextual Teaching and Learning. To know the effectiveness of the information service using Contextual Teaching and Learning model in preventing student' s abuse needs research, to be done sexual abuse behavior. There is no research found that explains how effective information services using the contextual teaching and learning model for preventing sexual abuse in schools.

Method 
The research method used was Quantitative Quasi Experimental type with Time Series Design. The subjects of this study were grade XI Science as experimental group and grade XI social as control group in SMA Baiturrahmah Padang. Determination of this research subject was using purposive sampling technique. The instruments used in this study was self-prepared sexual abuse scales which have been tested for their validity and reliability. Data analysis technique used were Kolmogorov Smirnov 2 Independent Sample.

\section{Results and Discussion}

1. Information services using contextual teaching and learning preventing sexual abuse

The data in this study is the total score for sexual abuse from experiment and control group before and after given treatment.

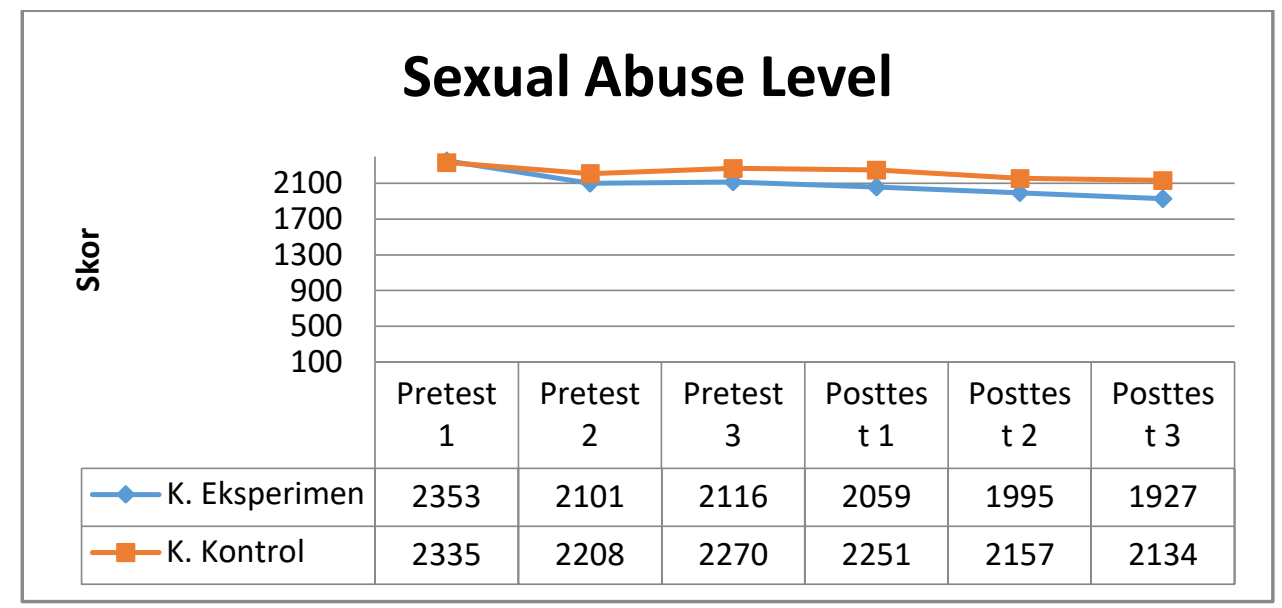

Graph 1. Sexual Abuse Level

Based on Graph 1, it is known that there are differences in scores between the experiment and control groups on pretest 1 , pretest 2 , pretest 3 , posttest 1 , posttest 2 and posttest 3 . In addition, it can be seen that in the pretest and posttest scores of the experiment group and control group experiencing instability. This indicates that the existence of external validity that can not be controlled by the researcher, and also the validity influence the student sexual abuse as the subject of this research. Furthermore, in the graph 1 there was a decrease score in the experimental group after being given information service treatment with contextual teaching and learning approach. The data shows that information service with contextual teaching and learning approach is more effective than information service given without contextual teaching and learning approach.

Based on the condition of student sexual abuse, the information services was given with contextual teaching and learning approach to experiment group, and information service without contextual teaching and learning approach to control group to prevent student sexual abuse. Sanjaya (2008) explains that the contextual teaching and learning approach is a strategy that emphasizes the full engagement process of students in order to be able to find the learning material and relate it to real life situations so as to encourage students to apply it in their lives.

Furthermore, on of the purpose of information services according to Prayitno \& Amti (2004) is to provide individuals with various knowledge about the environment needed to solve problems with respect to the environment, education, position, and social culture. Ananda (2016) explained that one of the causes of sexual harassment by adolescence is the lack of knowledge and sex eucation. (Prayitno, 2015; Mirnayenti, Syahniar, \& Alizamar, 2017) explained that information services are given as an understanding and prevention, with the purpose of information given to students should provide understanding of students, which can prevent the occurrence of problems that will disrupt life. Thus, through information services with contextual teaching and learning approach, students their gain an understanding of sexual harassment behavior causing social problems, so that students' understanding can prevent the occurrence of sexual harassment.

2. The effectiveness of information services using contextual teaching and learning in the prevention of sexual abuse.

Based on the results of an analysis test using the Wilcoxon Signed Rank Test to test the effectiveness of the experimental group and the control group before and after treatment show that the experimental group 
and the control group were equally effective in preventing sexual harassment. The test results of experimental group analysis before and after treatment was 0.005 , while in the control group before and after treatment was 0.042 . To test the effectiveness of the experimental group and the control group was used Kolmogorof Smirnov 2 independent sample, thus the result that there are significant differences between the experimental group and the control group after being given the information service using contextual teaching and learning. Thus, it can be seen that information services with contextual teaching and learning are more effective than information service without contextual teaching and learning in preventing sexual harassment.

Information services with contextual teaching and learning approach can help students to understand and prevent sexual harassment through the discussion of a topic that often occurs in the community. This opinion was supported by the result information services with contextual teaching and learning approach to prevent sexual harassment of students who are in the medium category.

Supporting the results of the study, (Hanson \& Pascoe, 1985; Ashby \& Verner, 2016) explained that one of the interventions that can be done to prevent of sexual harassment is to counselor. The information service is one type of counseling service that can be provided to students. The information provided can serve to provide understanding and prevent sexual harassment. Furthermore, Suryawati, Osman \& Meerah (2010) explained that the contextual teaching and learning approach is very effectively used to improve students' behavior, because contextual teaching and learning is an approach that links the material with real life and plays a role in activating students in their learning process. given to the child can be applied in everyday life. The previous opinion is supported by Firman (2009) that the paradigm shift in education suggests that learning is focused on the students (student center learning). Thus the contextual teaching and learning approach can be used to prevent sexual harassment.

Opinion from previous experts strengthened the results of this study. However, in this study, the researchers combined information services with contextual teaching and learning approach. In the research process, a the professional teacher needed, as Schetky (1998) argues that one of the special skills needed by a teacher in preventing sexual harassment is his professionalism (Ardi, Ibrahim, \& Said, 2012; Ardi \& Sukmawati, 2017; Ardi \& Yendi, 2017; Daharnis \& Ardi, 2016). Professionalism possessed by the teacher in using the method will give effect to the material presented and the students' understanding. Thus the results of this study states that sexual harassment can be prevented after being given information services using contextual teaching and learning.

\section{Conclusion}

The results showed that student' s sexual abuse was in the medium category, which can be concluded that the sexual abuse among students is still exist. One of the factors causing sexual harassment is lack of knowledge and sex education for adolescents. So, school counselor has responsibility to prevent problems that arise due to sexual harassment. Special discussions about sexual harassment prevention by the couselor have not been done yet, So the results of this study can be use by the counselor in guidance and counseling, one of the result is using information services with contextual teaching and learning.

\section{References}

Ananda, Y. R. 2016. " Penanganan Korban Pelecehan Seksual dengan Menggunakan Pendekatan Konseling Islami” . Dalam Syahniar (Eds), Proceeding 4th International Counseling Seminar 2016. Padang: UNP.

Ary. 2010. Introduction to Research in Education. Wadsworth: Cengage Learning

Ardi, Z., \& Sukmawati, I. (2017). Social Media and the Quality of Subjective Well-Being; Counseling Perspective in Digital Era. Open Science Framework. October, 15.

Ardi, Z., \& Erlamsyah, E. (2017). Peningkatan Kualitas Penulisan Artikel Ilmiah bagi Kepala Sekolah. Jurnal Aplikasi IPTEK Indonesia, 1(1), 25-34.

Ardi, Z., \& Yendi, F. M. (2017). Students Attitude Towards LGBTQ; the Future Counselor Challenges. Jurnal Konseling dan Pendidikan, 5(2), 74-79.

Ardi, Z., Ibrahim, Y., \& Said, A. (2012). Capaian Tugas Perkembangan Sosial Siswa dengan Kelompok Teman Sebaya dan Implikasinya terhadap Program Pelayanan Bimbingan dan Konseling. Konselor, 1(2).

Ashby, H. U., \& Verner, D. 2016. Do Pastoral Counselors Have a Duty to Report Clergy Sexual Abuse Done by Their Clergy Clients?. The University of Auckland Library, 5 (2016), 1-11 
Asra, Y. K. (2013). Efektivitas Psikoedukasi Pada Orangtua Dalam Meningkatan Pengetahuan Seksualitas Remaja Retardasi Mental Ringan. Jurnal Psikologi, 9(1), 64-72.

Cromer, L. D., \& Goldsmith, R. E. 2010. Child Sexual Abuse Myths: Attitudes, beliefs, and individual differences. Journal of Child Sexual Abuse, 19 (2010) 618-647

Edinburg, L. Saewyc, E., \& Levitt, C. 2006. Gender Differences in Extrafamilial Sexual Abuse Experiences Among Young Teens. The Journal of School Nursing, 22 (5), 278-284

Erhamwilda \& Afrianti, N. 2015. " Analysis on Early Childhood Sexual Abuse and The Implication in Islamic Education” . Psychological Bulletin. 2 (1): 105-126.

Firman. 2009. “ Tanggung Jawab Profesi Guru dalam Era Teknologi Informasi” . Jurnal Ilmiah Ilmu Pendidikan. 9 (1): 89-100.

Fuadi, M. A. 2011. Dinamika Psikologis Kekerasan Seksual: Sebuah studi fenomenologi. Malang: UIN Malang.

Gannon, T. A., \& Alleyne, E. K. A. 2013. Female Sexual Abusers' Cognition: A systematic review. Trauma, Violence, \& Abuse, $14(1), 67-79$

Goldman, J. D. G., \& Padayachi, U. K. 2005. Child Sexual Abuse Reporting Behaviour by School Counsellors and Their Need for Further Education. Health Education Journal. 64 (4) 302-322

Haluan. 2016. 15 November. Sumbar Darurat Pelecehan Seksual. (online) harianhaluan.com diakses pada Senin, 27 Februari 2017.

Hanson, G. \& Pascoe, D. 1985. " Intervention with Sexually Abused Children " . The Regents of the University of California for MOBIUS, 5 (1): 66-77.

Hermayeni, L., \& Aviani, Y. I. (2017). Gambaran penerimaan diri orangtua terhadap Anak yang menjadi korban Pelecehan seksual. Jurnal RAP, 7(1), 44-54.

Hepper, P. P., Wampold, B. E., \& Kivlinghan, D. M. 2008. Research Design in Counseling. California: Thomson Brooks/Cole

Homma, Y., Wang, N., Saewyc, E., \& Kishor, N. 2012. The Relationship Between Sexual Abuse and Risky Sexual Behavior Among Adolescent Boys: A Meta-Analysis. Journal of Adolescent Health, 51 (2012), 18-24.

Khairunnisa, A. (2013). Hubungan religiusitas dan kontrol diri dengan perilaku seksual pranikah remaja di MAN 1 Samarinda. Ejournal psikologi, 1(2), 220-229.

Komisi Perlindungan Anak Indonesia. 2016. Tabulasi Data Kasus Anak. (online) KPAI.go.id. diakses pada tanggal 27 Februari 2016.

Kusmiran, E. 2012. Kesehatan Reproduksi Remaja dan Wanita. Jakarta: Salemba Medika.

Loeb, T. B., Rivkin, I., Williams, J. K., Wyatt, G. E., Carmona, J. V., \& Chin, D. 2014. Child Sexual Abuse: Associations with the sexual functioning of adolescents and adults. Annual Review of Sex Research, 13(1), 307-345

Mudjiran. 2007. Perkembangan Peserta Didik. Padang: UNP Press.

MacMartin, C. \& Wood, L. A. 2005. Sexual Motives and Sentencing Judicial Discourse in Cases of Child Sexual Abuse. Journal of Language and Social Psychology, 24 (2), 139-159

Mirnayenti, M., Syahniar, S., \& Alizamar, A. (2017). Efektivitas Layanan Informasi Menggunakan Media Animasi Meningkatkan Sikap Anti Bullying Peserta Didik. Insight: Jurnal Bimbingan Dan Konseling, 6(2), 176-184.

Paramastri, I., \& Priyanto, M. A. (2010). Early prevention toward sexual abuse on children. Jurnal Psikologi, $37(1), 1-12$.

Phasha, N. 2012." Sexual Abuse Of Teenagers With Intellektual Disability: An Examination Of South African Literature" . Social and Behavioral Sciences. 69 (2012): 1693-1699.

Plummer, M., \& Cossing, A. 2016. The Cycle of Abuse: When victims become offenders. Trauma, Violence and Abuse, 22 (2016), 1-19

Pranungsari, D., \& Kushartati, K. S. (2014). Psychoeducational of Healthy Dating to Reduce the Risk of Sexual Violence in Female Street Children. Journal of Educational, Health and Community Psychology, 3(3), 126-140. 
Prayitno, Wibowo, M. E., Marjohan, Mugiarso, H., \& Ifdil. 2015. Pembelajaran Melalui Pelayanan BK di Satuan Pendidikan. Jakarta: Paramitra.

Prayitno. 2004. L1-L9. Padang: BK FIP UNP.

Rusman. 2010. Model-model Pembelajaran Mengembangkan Profesionalisme Guru. Jakarta: PT RajaGrafindo.

Sanjaya, W. 2008. Strategi Pembelajaran Berorientasi Standar Proses Pendidikan. Jakarta: Kencana.

Sari, A. K. 2016. “ Remaja, Pelecehan Seksual dan Bimbingan Kelompok” . Dalam Syahniar (Eds), Proceeding 4th International Counseling Seminar 2016. Padang: UNP.

Schetky, D. H. 1988. " Guidelines for the Clinical Evaluation of Child and Adolescent Sexual Abuse" . Council of the American Academy of Child and Adolescent Psychiatry. 1 (1): 655-657.

Schober, D. J., Fawcett, S. B., Thigpen, S., Curtis, A., \& Wright, R. 2011. An Empirical Case Study of a Child Sexual Abuse Prevention Initiative in Georgia. Health Eduacation Journal, 71 (3), 291-298

Suryawati, E., Osman, K. \& Meerah, T. S. M. 2016. " The Effectiveness of RANGKA Contextual Teaching and Learning on Student' s Problem Solving Skills and Scientific Attitude" . Procedia Social and Behavioral Sciences. 9 (2010): 1717-1721.

Tayo, A. B. \& Olawuyi, B. O. 2016. " Parental Communication as a Tool for Preventing Sexual Abuse among Adolescent Secondary School Students" . Journal of Education and Practice. 7 (13): 116-123.

Waldron, J. C., Scarpa, A., Kim-Spoon, J., \& Coe, C. J. Adult Sexual Experiences as a Mediator Between Child Abuse and Current Secretory Immunoglobulin A Levels. Journal of Interpersonal Violence, 14(2015), 119

Wohab, M. A. \& Akhter, S. 2010. " The Effects of Childhood Sexual Abuse on Children' s Psychology and Employment” . Procedia Social and Behavioral Sciences. 5 (2010): 144-149. 